\title{
Examination of the Perceptions about Self-Efficacy in Environmental Education amongst Social Studies Teacher Candidates
}

\author{
Gökçe KILIÇOĞLU1
}

Gazi University, Ankara, TURKEY

${ }^{1}$ Assoc. Prof. Gazi University, Faculty of Education, Department of Social Studies Education, Ankara, TURKEY. gkilicoglu@gazi.edu.tr. ORCID: 0000-0002-6125-1853

\begin{abstract}
Self-efficacy is the belief in one's own knowledge, skills and attitudes. This belief significantly affects a person's ability to start, continue, and complete a job. The ability of teacher candidates to have the competencies required by the teaching profession, and to use these competencies effectively, to fulfill the duties and responsibilities required by their profession depends significantly on their self-efficacy. One of the self-efficacy beliefs relates to environmental education. The status of competencies in the self-efficacy of environmental education for teacher candidates' is essential: individual beliefs towards their environment, creating awareness for environmental issues; knowledge, skills and attitudes that enable to develop environmental education. In this study, it was aimed to investigate the perceptions of self-efficacy in environmental education amongst Social Studies teacher candidates according to gender, class level, taking courses with environmental content, membership in an environmental association. The research was conducted as a survey with 155 teacher candidates studying in the Social Studies Education undergraduate program during the 2019-2020 academic year. A personal data form of four dimensions (academic competence perception, responsibility perception, educational competence perception, orientation perception) and an "environmental education self-efficacy perception scale" consisting of 15 items were used as the data collection tools. Data was analyzed using SPSS 20 statistical program. In the study, nonparametric analyses of the MannWhitney-U test and the Kruskal Wallis $\mathrm{H}$ test were used for an unrelated sample, because descriptive statistics and data obtained from each variable-level scale did not show a normal distribution. As a result of the research, significant differences were found between the scores of Social Studies teacher candidates according to the following criteria: class level in the 'academic competence perception dimension', gender in the 'responsibility perception dimension', and status of membership in the environmental organization in the "educational competence perception dimension".
\end{abstract}

Keywords

Environmental Education; Self-Efficacy; Environmental Education Self-Efficacy; Candidate Teacher

To cite this article: Kulıçoğlu, G. (2021), Examination of the perceptions about self-efficacy in environmental education amongst social studies teacher candidates. Review of International Geographical Education (RIGEO), 11(1), 118-133, doi: 10.33403 rigeo.841359 
In recent years, one of the important concepts focused on in Social Science is self-efficacy. Self-efficacy is one of the basic concepts of social learning theory (Bandura, 1997); it refers to the effort shown in the face of any situation - a person's performance to put forth a particular capacity to organize these activities and the activities needed to successfully perform a belief which considers it to be about itself. In the individual, this belief is formed by making self-evaluations and judgments. Self-efficacy in doing a job is very important. Individuals with high selfefficacy can think in a multi-faceted way when faced with a problem and can produce different solutions to the problem (Bandura, 1989). People with high selfefficacy can also perform at higher levels when doing a job faced for the first time (Bandura, 1982), and can deal with events effectively, and they do not refrain from the actions they took in order to successfully complete the task and remain stable (Bandura, 1997). People with high self-efficacy can produce results in a shorter period of time and are capable of achieving their work and are quite successful in solving the problems (Altunçekiç, Yaman \& Koray, 2005); they can work much more comfortably and productively when faced with higher levels of difficulty (Pajares, 2002). Those with high self-efficacy can accept difficult jobs not as a danger to avoid, but as difficult jobs to achieve (Turcan, 2011). All these characteristics show that individuals with high self-efficacy are strong, selfconfident and self-aware.

A person continues their life as a social being in society. The confidence and responsibilities given to the individual in the society in which they live will develop their sense of self-efficacy. However, formal educational institutions are also important for developing the self-efficacy of the individual as well as society; in particular, the role of teachers responsible for directing courses in these institutions is too great to be underestimated (Önen \& Öztuna, 2005). From this point of view, it can be said that the teacher's self-efficacy belief must also be high in order for their students to develop their own self-efficacy. If the self-efficacy beliefs of teachers are strong, this belief positively affects the development of their students, as well as positively affecting the ability of teachers to perform their tasks more successfully and selflessly. Teachers with strong self-efficacy beliefs can be more willing, more patient and caring towards their students in their lessons, and can also use time effectively. In other words, the success of the teacher brings about the success of the student (Aydın, 2008). In order for teachers to carry out effective education, it is very important that they can understand the issues they are talking about, have strong self-efficacy beliefs in many issues, such as their activities in the classroom and their attitude towards their students.

A teachers' ability to have the competencies required by their profession, to use these competencies effectively, and to fulfill the requirements of their profession depends significantly on their self-efficacy (Türk, 2008; Azar, 2010; Miller, Ramirez \& Murdock, 2017; Ünlü, Kaşkaya \& Kızılkaya, 2017; Koçak Macun, Macun \& Safalı, 2019; Recepoğlu \& Recepoğlu, 2020). In this sense, teachers should have a strong self-efficacy about many issues. One of these self-efficacy beliefs is about environmental education. In order to achieve the desired success from environmental education, teachers who will give environmental education lesson must have sufficient knowledge, especially about environmental issues; they must 
also be sensitive towards the environment, environmental problems, and believe that they can take responsibility for these issues and fulfill such responsibilities.

Environmental education refers to the process of: developing attitudes, values, knowledge and skills to protect the environment; revealing environmentally sensitive behaviors; and seeing positive results brought about by sensitivity to the environment (Erten, 2004). Environmental education is for individuals to understand the environment, to recognize its place and role in the environment, to perceive various factors that affect the environment, and to raise awareness in this sense (Özbuğutu, Karahan \& Tan, 2014). Environmental awareness and environmental sensitivity demonstrated by an individual may be possible in a long process that begins in the family from an early age and then continues in school. For this reason, a person should be able to continue the education they receive in the family at school (Yilmaz, 2016).

The primary curriculum allows for the development of environmental awareness in individuals across different topics in the curriculum at all levels of the undergraduate program. In order to achieve the desired results from environmental education, teachers who will teach environmental education must have sufficient knowledge of the environment, awareness about environmental problems, and be environmentally friendly people. In addition to these characteristics, teachers should also have full faith that they can fulfill the responsibilities they take on (Erkol \& Erbasan, 2018). In order for teacher candidates to provide effectively environmental education in their professional lives, it is very important that they have a high level of self-efficacy about environmental education. Therefore, if teacher candidates can improve their selfefficacy in environmental education and turn them into skills, their performance will increase. Therefore, in order to determine the methods and techniques to increase the self-efficacy of teacher candidates this issue should be emphasized in schools (Özdemir, Aydın \& Akar Vural, 2009). In this context, it is very important to determine the levels of their self-efficacy beliefs for environmental education, as teacher candidates will play an important role in providing environmental education in the future (Özlü, 2012).

In terms of the Social Studies courses that contain environmental issues, it is very important that teacher candidates who will teach this course in the future grow up with this consciousness. This is because teacher candidates who grow up with this consciousness and self-efficacy will play an effective role in the education of people who build and shape the environment, are sensitive to the environment, and have a high level of awareness in the future. The environmental education selfefficacy of Social Studies teacher candidates in this study are examined across different variables (gender, being a member of environmental organizations of the state, the status of environmental lessons, grade level). In the current study, the self-efficacy in environmental education is intended to answer the following subproblems.

1. Does the average score of Social Studies teacher candidates in the lower dimensions of the environmental education self-efficacy perception scale differ by gender? 
2. Does the average score of Social Studies teacher candidates in the lower dimensions of the environmental education self-efficacy perception scale differ according to the status of membership in the environmental organization?

3. Does the average score of Social Studies teacher candidates in the lower dimensions of the environmental education self-efficacy perception scale differ depending on the state of taking an environmental course?

4. Does the average score of Social Studies teacher candidates in the lower dimensions of the environmental education self-efficacy perception scale differ according to class level?

\section{Methodology}

\section{Model of the Research}

This study aims to examine the self-efficacy perceptions of Social Studies teacher candidates for environmental education in terms of different variables. Survey models are a research approach aimed at describing a situation that exists in the past or still, as it exists (Karasar, 1999).

\section{Working Group}

The research-working group consists of 155 Social Studies teacher candidates studying at a state university in the province of Ankara during the 2018-2019 academic year.

\section{Data Collection Tools}

The environmental education self-efficacy perception scale developed by Aydın (2008) was used to collect data. The scale consists of four sub-dimensions: "academic competence perception", "responsibility perception", "educational competence perception" and "orientation perception"; in total 15 items. A Likertscale with 5 are rated as Strongly disagree =1; Disagree =2; Undecided =3; Agree $=4$; Strongly agree $=5$. Aydin (2008) determined the overall reliability co-efficient of the scale as $\alpha=0.76$. The reliability co-efficient of the lower dimensions were determined as $\alpha=0.79$ for academic competence perception, $\alpha=0.86$ for responsibility perception, $\alpha=0.74$ for educational competence perception, and $\alpha=$ 0.68 for orientation perception. In this study, the reliability of the environmental education self-efficacy perception scale was examined again. Accordingly, the overall reliability co-efficient of the scale is $\alpha=0.81$, and the reliability co-efficient calculated for their lower dimensions are $\alpha=0.83$ for academic competence perception; $\alpha=0.87$ for responsibility perception; $\alpha=0.72$ for competence perception, and $\alpha=0.69$ for orientation perception.

\section{Data Analysis}

The Kolmogorov-Smirnov test looked at whether the data obtained in the study showed normal distribution characteristics. According to the results of the Kolmogorov-Smirnov test, it was found that the research data did not show a normal distribution. The data obtained from the scale of each variable used in the 
study showed the level of a normal distribution, since in the analysis of the data; Unbound sample Mann-Whitney $U$ test and Kruskal Wallis $H$ test techniques, nonparametric statistics were used.

Table 1

Results of the Kolmogorov-Smirnov Test for Normality of Research Data Distribution Kolmogorov-Smirnova

\begin{tabular}{lccc} 
& Statistic & df & p \\
\hline Gender &, 438 & 155 &, 000 \\
\hline Grade &, 191 & 155 &, 000 \\
\hline Course &, 359 & 155 &, 000 \\
\hline Organization &, 523 & 155 &, 000 \\
\hline
\end{tabular}

In Table 1, according to the results of the Kolmogorov-Smirnov test, it was found that the data obtained from the scale used in the study did not show a normal distribution at each variable level. The Kolmogorov-Smirnov test is used to test the normal distribution of data in groups with a sample size greater than 30 . In cases where there is a value of significance $(p<, 05)$, the distribution of research data is interpreted in such a way that it is not normal, and non-parametric tests are performed (Can, 2019).

\section{Findings}

In this section of the study, the findings obtained from the analysis of the data obtained from the data collection tool are included. These findings are tabulated according to the gender of Social Studies teacher candidates, the status of membership in an environmental organization, the status of taking an environmental course, and the level of class.

Table 2

Distribution of Descriptive Values Related to Environmental Education Self-Efficacy Perceptions of Social Studies Teacher Candidates

\begin{tabular}{llll}
\hline \multicolumn{1}{c}{ Scale } & $\mathrm{N}$ & $\overline{\mathrm{x}}$ & $\mathrm{SS}$ \\
\hline Perception of academic competence & 155 & 3,18 &, 667 \\
\hline Perception of responsibility & 155 & 3,58 &, 897 \\
\hline Educational competence perception & & & \\
\hline Perception of orientation & 155 & 3,87 &, 656 \\
\hline Environmental education self-efficacy perception & 155 & 3,40 &, 867 \\
\hline
\end{tabular}

In Table 2, it is seen that the average score of Social Studies teacher candidates in the lower dimensions of the environmental education self-efficacy perception 
Kilıçoğlu, G. (2021). Examination of the perceptions about self-efficacy in environmental.....

scale is listed as the size of educational competence perception $(x=3.87)$, responsibility perception $(\mathrm{x}=3.58)$, orientation perception $(\mathrm{x}=3.40)$ and academic competence perception ( $\mathrm{x}=3.18)$. When the results of the analysis are evaluated, it is understood that Social Studies teacher candidates scores in the environmental education self-efficacy levels on a 5 point Likert scale show a mid-point (3) value $(x=3.44)$. Therefore, teacher candidates Show a mid-level of self-efficacy about environmental education.

\section{Findings for First Sub-Problem}

The first sub-problem of the study is, "Does the average score of Social Studies teacher candidates in the sub-dimensions of the environmental education selfefficacy perception scale differ by gender? It is expressed as "1" and statistical data on the sub-problem are presented in Table 3.

Table 3

Results of the Mann Whitney $U$ test for the Difference in Environmental Education SelfEfficacy Perceptions of Social Studies Teacher Candidates According to Their Gender

\begin{tabular}{|c|c|c|c|c|c|c|}
\hline Scale & Gender & $\mathrm{N}$ & $\begin{array}{l}\text { Rank } \\
\text { Average }\end{array}$ & $\begin{array}{l}\text { Rank } \\
\text { Sum }\end{array}$ & $\mathrm{U}$ & $\mathrm{p}$ \\
\hline \multirow{3}{*}{$\begin{array}{l}\text { Perception of } \\
\text { academic } \\
\text { competence }\end{array}$} & Female & 107 & 75.74 & 8104.00 & \multirow{3}{*}{2326.000} & \multirow{3}{*}{.347} \\
\hline & Male & 48 & 83.04 & 3986.00 & & \\
\hline & Total & 155 & & & & \\
\hline \multirow{3}{*}{$\begin{array}{l}\text { Perception of } \\
\text { responsibility }\end{array}$} & Female & 107 & 83.79 & 8966.00 & \multirow{3}{*}{1948.000} & \multirow{3}{*}{$.015^{*}$} \\
\hline & Male & 48 & 65.08 & 3124.00 & & \\
\hline & Total & 155 & & & & \\
\hline \multirow{3}{*}{$\begin{array}{l}\text { Educational } \\
\text { competence } \\
\text { perception }\end{array}$} & Female & 107 & 79.86 & 8544.50 & \multirow{3}{*}{2369.500} & \multirow{3}{*}{.435} \\
\hline & Male & 48 & 73.86 & 3545.50 & & \\
\hline & Total & 155 & & & & \\
\hline \multirow{4}{*}{$\begin{array}{l}\text { Perception of } \\
\text { orientation }\end{array}$} & Female & 107 & 77.23 & 8264.00 & \multirow{4}{*}{2486.000} & \multirow{4}{*}{.749} \\
\hline & Male & 48 & 79.71 & 3826.00 & & \\
\hline & Total & 155 & & & & \\
\hline & Total & 155 & & & & \\
\hline
\end{tabular}

According to the results of the analysis in Table 3, the environmental education self-efficacy of Social Studies teacher candidates in academic competence perception size scores did not differ significantly according to the gender variable $(\mathrm{U}=2326.000 ; \mathrm{p}>, 05)$.

Environmental education self-efficacy responsibility perception size scores of Social Studies teacher candidates differed significantly according to the gender variable $(U=1948,000 ; p<, 05)$. When the ranking averages are examined, it is understood that the difference in question is in favor of female teacher candidates.

Environmental education self-efficacy of Social Studies teacher candidates educational competence perception size scores did not differ significantly according to the gender variable $(U=2369.500 ; p>, 05)$. 
Social Studies teacher candidates' environmental education self-efficacy orientation perception size scores did not differ significantly according to the gender variable $(U=2486.000 ; p>, 05)$.

\section{Findings for Second Sub-Problem}

The second sub-problem of the study is, "Does the average score of the Social Studies teacher candidates sub-dimensions of the environmental education selfefficacy perception scale differ depending on the status of membership in the environmental organization? It is expressed as "2" and the statistical data on the sub-problem are presented in Table 4.

Table 4

Results of the Mann Whitney U Test for the Difference in Environmental Education SelfEfficacy Perceptions of Social Studies Teacher Candidates Compared to Their Status as a Member of an Environmental Organization

\begin{tabular}{|c|c|c|c|c|c|c|}
\hline Scale & $\begin{array}{l}\text { Status of } \\
\text { Membership in an } \\
\text { Environmental } \\
\text { Organization }\end{array}$ & $\mathrm{N}$ & $\begin{array}{l}\text { Rank } \\
\text { Average }\end{array}$ & Rank Sum & U & $\mathrm{p}$ \\
\hline \multirow{3}{*}{$\begin{array}{l}\text { Perception of } \\
\text { academic } \\
\text { competence }\end{array}$} & Yes & 19 & 93.74 & 1781.00 & \multirow{3}{*}{993.000} & \multirow{3}{*}{.101} \\
\hline & No & 136 & 75.80 & 10309.00 & & \\
\hline & Total & 155 & & & & \\
\hline \multirow{3}{*}{$\begin{array}{l}\text { Perception of } \\
\text { responsibility }\end{array}$} & Yes & 19 & 93.32 & 1773.00 & \multirow{3}{*}{1001.000} & \multirow{3}{*}{.109} \\
\hline & No & 136 & 75.86 & 10317.00 & & \\
\hline & Total & 155 & & & & \\
\hline \multirow{3}{*}{$\begin{array}{l}\text { Educational } \\
\text { competence } \\
\text { perception }\end{array}$} & Yes & 19 & 104.68 & 1989.00 & \multirow{3}{*}{785.000} & \multirow{3}{*}{$005^{*}$} \\
\hline & No & 136 & 74.27 & 10101.00 & & \\
\hline & $\overline{\text { Total }}$ & 155 & & & & \\
\hline \multirow{3}{*}{$\begin{array}{l}\text { Perception of } \\
\text { orientation }\end{array}$} & Yes & 19 & 87.21 & 1657.00 & \multirow{3}{*}{1117.000} & \multirow{3}{*}{.336} \\
\hline & No & 136 & 76.71 & 10433.00 & & \\
\hline & $\overline{\text { Total }}$ & 155 & & & & \\
\hline
\end{tabular}

According to the results of the analysis in Table 4, the environmental education self-efficacy of Social Studies teacher candidates academic competence perception size scores did not differ significantly compared to the variable of membership in an environmental organization $(U=993.000 ; p>, 05)$.

Environmental education self-efficacy of Social Studies teacher candidates the size of responsibility perception scores did not differ significantly compared to the variable of membership in an environmental organization $(U=1001.000 ; p>, 05)$.

Environmental education self-efficacy of Social Studies teacher candidates educational competence perception size scores differed significantly compared to the variable of membership in an environmental organization $(U=785,000 ; p<, 05)$. By examining the rank averages, it is understood that this difference is in favor of those who are members of the environmental organization. 
Kılıçoğlu, G. (2021). Examination of the perceptions about self-efficacy in environmental.....

Environmental education self-efficacy of Social Studies teacher candidates' perception size scores did not differ significantly compared to the variable of membership in an environmental organization $(U=1117.000 ; p>, 05)$.

\section{Findings for Third Sub-Problem}

The third sub-problem of the study is, "Does the average score of the Social Studies teacher candidates in the sub-dimensions of environmental education selfefficacy perception scale differ depending on the state of taking an environmental course? It is expressed as " 3 " and the statistical data about the sub-problem are presented in Table 5.

Table 5

Results of the Mann Whitney U Test for the Difference in Environmental Education SelfEfficacy Perceptions of Social Studies Teacher Candidates Compared to Their Environmental Course-Taking Status

\begin{tabular}{|c|c|c|c|c|c|c|}
\hline Scale & $\begin{array}{l}\text { Environmental } \\
\text { Course Status }\end{array}$ & $\mathrm{N}$ & $\begin{array}{l}\text { Rank } \\
\text { Average }\end{array}$ & $\begin{array}{l}\text { Rank } \\
\text { Sum }\end{array}$ & U & $\mathrm{p}$ \\
\hline \multirow{3}{*}{$\begin{array}{l}\text { Perception of } \\
\text { academic } \\
\text { competence }\end{array}$} & Yes & 72 & 88.53 & 6374.00 & \multirow{3}{*}{2230.000} & \multirow{3}{*}{$.006^{*}$} \\
\hline & No & 83 & 68.87 & 5716.00 & & \\
\hline & Total & 155 & & & & \\
\hline \multirow{3}{*}{$\begin{array}{l}\text { Perception of } \\
\text { responsibility }\end{array}$} & Yes & 72 & 74.85 & 5389.00 & \multirow{3}{*}{2761.000} & \multirow{3}{*}{.411} \\
\hline & No & 83 & 80.73 & 6701.00 & & \\
\hline & Total & 155 & & & & \\
\hline \multirow{3}{*}{$\begin{array}{l}\text { Educational } \\
\text { competence } \\
\text { perception }\end{array}$} & Yes & 72 & 82.02 & 5905.50 & \multirow{3}{*}{2698.500} & \multirow{3}{*}{.292} \\
\hline & No & 83 & 74.51 & 6184.50 & & \\
\hline & Total & 155 & & & & \\
\hline \multirow{3}{*}{$\begin{array}{l}\text { Perception of } \\
\text { orientation }\end{array}$} & Yes & 72 & 85.23 & 6136.50 & \multirow{3}{*}{\multicolumn{2}{|c|}{2467.500 .060}} \\
\hline & No & 83 & 71.73 & 5953.50 & & \\
\hline & $\overline{\text { Total }}$ & 155 & & & & \\
\hline
\end{tabular}

According to the results of the analysis in Table 5, the environmental education self-efficacy of Social Studies teacher candidates academic competence perception size scores differed significantly compared to the environmental course taking variable $(U=2230,000 ; p<, 05)$. By examining the rank averages, it is understood this difference is in favor of those who take environmental courses.

Environmental education self-efficacy of Social Studies teacher candidates for the size of responsibility perception scores did not differ significantly compared to the environment course taking variable $(U=2761.000 ; p>, 05)$.

Environmental education self-efficacy of Social Studies teacher candidates educational competence perception size scores did not differ significantly compared to the environmental course taking variable $(U=2698.500 ; p>, 05)$.

Environmental education self-efficacy scores of Social Studies teacher candidates' perception size did not differ significantly compared to the environmental course taking variable $(U=2467.500 ; p>, 05)$. 


\section{Findings for Fourth Sub-Problem}

The fourth sub-problem of the study is, "Does the average score of the Social Studies teacher candidates sub-dimensions of the environmental education selfefficacy perception scale differ according to class level? It is expressed as "4" and the statistical data about the sub-problem are presented in Table 6.

Table 6

Kruskal Wallis $H$ Test Results for the Difference of Environmental Education Self-Efficacy Perceptions of Social Studies Teacher Candidates by Class Level

\begin{tabular}{|c|c|c|c|c|c|c|}
\hline Scale & Grade & $\mathrm{N}$ & Rank Average & $\mathrm{X}^{2}$ & $\mathrm{p}$ & Significant \\
\hline \multirow{5}{*}{$\begin{array}{l}\text { Perception of } \\
\text { Academic } \\
\text { Competence }\end{array}$} & 1. Grade & 40 & 61.68 & \multirow{5}{*}{12.592} & \multirow{5}{*}{$.006^{*}$} & \multirow{5}{*}{$\begin{array}{l}1-3 \\
2-3\end{array}$} \\
\hline & 2. Grade & 34 & 72.21 & & & \\
\hline & 3. Grade & 43 & 95.45 & & & \\
\hline & 4. Grade & 38 & 80.62 & & & \\
\hline & Total & 155 & & & & \\
\hline \multirow{5}{*}{$\begin{array}{l}\text { Perception of } \\
\text { Responsibility }\end{array}$} & 1. Grade & 40 & 74.90 & \multirow{5}{*}{5.166} & \multirow{5}{*}{.160} & \\
\hline & 2. Grade & 34 & 65.25 & & & \\
\hline & 3. Grade & 43 & 87.09 & & & \\
\hline & 4. Grade & 38 & 82.38 & & & \\
\hline & Total & 155 & & & & \\
\hline \multirow{5}{*}{$\begin{array}{l}\text { Educational } \\
\text { Competence } \\
\text { Perception }\end{array}$} & 1. Grade & 40 & 80.93 & \multirow{5}{*}{.494} & & \\
\hline & 2. Grade & 34 & 74.07 & & \multirow{4}{*}{.920} & \\
\hline & 3. Grade & 43 & 79.22 & & & \\
\hline & 4. Grade & 38 & 77.05 & & & \\
\hline & Total & 155 & & & & \\
\hline \multirow{5}{*}{$\begin{array}{l}\text { Perception of } \\
\text { Orientation }\end{array}$} & 1. Grade & 40 & 80.31 & \multirow{5}{*}{2.799} & \multirow{5}{*}{.424} & \\
\hline & 2. Grade & 34 & 66.85 & & & \\
\hline & 3. Grade & 43 & 82.63 & & & \\
\hline & 4. Grade & 38 & 80.30 & & & \\
\hline & Total & 155 & & & & \\
\hline
\end{tabular}

According to the results of the analysis in Table 6, environmental education selfefficacy of Social Studies teacher candidates academic competence perception size scores differed significantly according to the class variable $(X 2=12.592 ; \mathrm{p}<, 05)$. According to the results of the multiple comparison test, a significant difference was found between 1st and 3rd, 2nd and 3rd year students. When the mean ranks are examined, it is understood that the aforementioned differences are in favor of the 2 nd grade among the 1st and 2 nd grade pre-service teachers, and among the 2nd and 3rd grade pre-service teachers in favor of the 3rd grade. This finding shows that the academic competence perceptions of 2 nd grade teacher candidates are higher than those of 1st grade, and 3rd grade teacher candidates are higher than those of 2 nd grade.

Environmental education self-efficacy responsibility perception size scores of Social Studies teacher candidates did not differ significantly compared to the class variable $\left(\mathrm{X}^{2}=5.166 ; \mathrm{p}>, 05\right)$. 
Environmental education self-efficacy of Social Studies teacher candidates educational competence perception size scores did not differ significantly compared to the class variable $\left(\mathrm{X}^{2}=.494 ; \mathrm{p}>, 05\right)$. Social Studies teacher candidates ' environmental education self-efficacy perception size scores did not differ significantly compared to the class variable $\left(X^{2}=2.799 ; p>, 05\right)$.

\section{Result and Discussion}

In this study, Social Studies teacher candidates' perceptions of self-efficacy for environmental education were examined in terms of different variables. First, the average scores of Social Studies teacher candidates from the environmental education self-efficacy perception scale were looked at and it was determined that the environmental education self-efficacy perceptions of teacher candidates were moderate. In parallel with this study in their work with student teachers Kahyaoğlu (2011), Okumuş and Öztürk (2019), Konakçı (2019), Çetkin (2019), Çingll Barış (2020) found the self-efficacy of teachers has a moderate risk in those studying environmental education. Apaydın-Timur (2020) stated in his study that Social Studies teachers have a high level of self-efficacy in environmental education. In other words, it is very important for teachers to feel adequate in environmental education lessons, as in many lessons, because their self-efficacy needs to be at a good level from the point of view of the teaching activities they will perform. Considering the results of the research, it can be said that Social Studies teacher candidates are environmentally conscious, are environmentally responsible, and are sensitive to the environment, they feel adequate about environmental education, and also have a good level of knowledge, skills and attitudes towards the environment. Karatekin and Aksoy (2012) in their study, which examined the environmental literacy levels of Social Studies teacher candidates, determined that the environmental literacy of teacher candidates in the dimensions of knowledge, skills and behavior was moderate. The results of the studies of Timur (2011), Koç and Karatekin (2013), Özyürek et al. (2019) also show parallels with this study.

In the current study, the average score of Social Studies teacher candidates on the lower dimensions of the environmental education self-efficacy scale was analyzed according to the gender variable. According to the results of the analysis, there was no difference between the average score of teacher candidates in the lower dimensions of academic competence, educational competence, perception of orientation according to the gender variable. However, a significant difference was found in favor of female teacher candidates in the lower dimension of perception of responsibility. The study of knowledge, attitude and behavior shows significant differences between groups according to gender and academic competence although there are not affective tendencies in the environment of undergraduate students in different programs (Aksoy \& Karatekin, 2011). In other words, the attitudes of teacher candidates in their studies are found to have significant differences between the mean score by gender. In parallel with this study, studies conducted by Aydın (2008) and Zayimoğlu Öztürk, Öztürk and Şahin (2015), Okumuş and Öztürk (2019) stated there were no significant differences between the average score of teacher candidates by gender in the lower dimensions of 
academic competence, educational competence and orientation perception. In a study conducted by Çıngıl Barış (2020), he found that, unlike this study, the average score of Science teacher candidates in the size of the teacher's competence differs significantly according to the gender variable. In contrast to these studies, significant differences in the size of responsibility perception were found in this study according to the gender of teacher candidates. Çetkin (2019) in his study, parallel to the current study, with students from a Faculty of Education, stated that the perception of environmental education self-efficacy in the lower dimension of responsibility of female teacher candidates is higher compared to those of male teacher candidates. Again, Çavuşoğlu (2019) determined that, unlike this study, the average score of teacher candidates in the dimension of responsibility perception differs, this difference is in favor of male teacher candidates. In a study conducted by Artun, Uzunöz and Akbaş (2013) which examined the environmental literacy levels of Social Studies teacher candidates, the environmental literacy survey found that there was no significant difference between the average score of male and female teacher candidates in the size of responsibility. This result of the study shows that when compared to male teacher candidates, the female teacher candidates have a higher perception of acceptance of responsibility in the future when their students exhibit environmental behaviors and internalize these behaviors.

From the environmental education self-efficacy scale for Social Studies teacher candidates, the average scores they receive for the sub-dimensions of the variables of becoming a member of an environmental organization, the scores received from the scale of perception of academic competence among teacher candidates, are in favor of those who join environmental organizations: to be able to direct perception and perception of responsibility of being a member of an environmental organization in lower dimensions. However, there are not significant differences according to the variable of tutorial perception of competence sub-dimensions in significant differences have been identified. In a study conducted by Arlk and Yllmaz (2017) about Science teacher candidates' perceptions and attitudes towards environmental issues, there was no effect shown about teacher candidate attitudes towards environmental issues in the work of investigating environmental agencies and environmental pollution.

As in many undergraduate programs in the Faculties of Education (Science, Biology, primary teaching), the undergraduate program of Social Studies education has courses that include the environment and the topics related to the environment. The main goal of the environmental education course in the Faculties of Education is to educate people to become sensitive towards the environment, to know the concepts related to the environment, and to master the issues related to the problems of the environment. In order to determine the effect of such courses taken at the undergraduate level on the perception of self-efficacy about environmental education, the average score obtained by Social Studies teacher candidates from the lower dimensions of the environmental education self-efficacy scale was analyzed according to the environment course intake variable. According to the results of the analysis, there were no significant differences between the average score of teacher candidates on the scale compared to the variable of taking 
an environmental course in the lower dimensions of responsibility, educational competence and orientation perception. However, a significant difference was found in favor of those who took an environmental course in the lower dimension of academic competence perception. Aydın (2008), and Zayimoğlu Öztürk, Öztürk and Şahin (2015) in their studies with teacher candidates, they found that there was no significant difference between the scores received by teacher candidates from the lower dimensions of the environmental education self-efficacy scale. In parallel with these studies, although in this study there were no significant differences in the lower dimensions of responsibility perception, educational competence perception and orientation perception, a significant difference was found in the size of academic competence perception in favor of those who took the environmental course. A similar result was found in the study conducted by Aydın (2008). Aydın (2008) in his study with class teacher candidates showed that there is a significant difference in the size of academic competence in favor of students taking environmental courses. In his study, Çıngıl Barış (2020) stated that there was a significant difference in the educational competence size in favor of those who took environmental courses between the average score of teacher candidates according to the environment course taking variable.

Karatekin and Aksoy (2012) found that Social Studies teacher candidates' environmental literacy levels, which include information, attitudes and behavioral dimensions, were higher in their studies aimed at determining environmental literacy levels. This supports the result determined in this study in favor of the candidates who took environmental courses in the academic competence dimension. Again, the Aksoy and Karatekin (2011) affective tendencies of teacher candidates in the environment receiving a course determined in environmental studies showed no significant difference in the average score of teacher candidates according to the state.

However, the scores for teacher candidates who took environmental education course compared to teacher candidates who do not take courses, were higher according to the average scores. Behavior based on this result of the study shows the academic competencies of environmental courses taken by teacher candidates at the undergraduate level can be interpreted as having a positive effect on improving and increasing their knowledge of environmental issues. Although there were no significant differences in score averages in other lower dimensions of the scale, it was found that the perception of competence and ability to guide teacher candidates who took environmental lessons was higher than the average ranking of students who did not. This can be considered as a positive effect on the perception of the environmental lessons/courses they take in teacher candidates about how they can guide themselves and their students in the future.

The average score of Social Studies teacher candidates from the lower dimensions of the self-efficacy scale for environmental education was analyzed according to the class variable. According to the results of the analysis, there were no significant differences between the average scores of teacher candidates compared to the class variable in the lower dimensions of responsibility, educational competence and orientation perception. However, differences were found in the lower dimension of academic competence and perception according 
to the level of the class. As a result of the analysis, this difference is for Grades 1 and 2., and Grades 2 and 3. And it was determined that the classes were in favor. This indicates that as the class level increases, students ' academic competencies related to the environment increases, in other words, their knowledge of the environment, increase. An increase in the knowledge of teacher candidates can be explained by the beginning of courses being related to the environment and involving environmental issues in the higher grades. In parallel with this study, Çavuşoğlu (2019) also found significant differences in the lower dimension of academic competence compared to the level of the class. However, unlike this study, Çavuşoğlu (2019) noted that there is a significant difference between averages in other dimensions of the scale. Again, unlike this study, Çıngıl Barış (2020) stated that there was a significant difference between the average score of teacher candidates according to the class level in the size of the perception of responsibility.

\section{Suggestions}

Based on the results of this study, in which an evaluation occurred about the perceptions of self-efficacy in environmental education amongst Social Studies teacher candidates in terms of different variables, the following suggestions are made.

- As a result of this study, it was determined that the perceptions of selfefficacy in environmental education amongst Social Studies teacher candidates were moderate. Self-efficacy is high amongst teachers who can express themselves more easily, are able to deal with problems more easily, and consider the positive contributions more readily because they are more efficient in their courses. Improvement and development of self-efficacy in environmental education amongst teacher candidates will occur before embarking on their careers in many areas.

- Considering that being intertwined with the environment will increase attitude, knowledge and awareness of the environment, giving importance to practice in environmental-related courses will make positive contributions to the self-efficacy of teacher candidates.

- In many studies, it has been found that environmental education courses contribute positively to students' self-efficacy. In this case, more attention should be paid to the development of environmental courses, also that environmental courses should be diversified in undergraduate programs.

- Teacher candidates should be encouraged to become members of environmental organizations and participate in environmental activities. 


\section{References}

Aksoy, B. \& Karatekin, K. (2011). Affective tendencies of undergraduate students in different programmes toward the environment. Turkish Journal of Social Research, 1(3), 23-36.

Altunçekiç, A., Yaman, S. \& Koray, Ö. (2005). The research on prospective teachers' selfefficacy belief level and problem solving skills. Kastamonu Education Journal, 13(1), 93-102.

Apaydın Timur, S. (2020). Study of self-efficacy levels of social studies teachers in the field of environmental education. (Unpublished master thesis), Aksaray University Institute of Social Sciences, Aksaray.

Arık, S. \& Yılmaz, M. (2017). Prospective science teachers' attitude toward the environmental problems and their metaphorical perceptions about "environmental pollution". Kastamonu Education Journal, 25(3), 1147-1164.

Artun, H., Uzunöz, A. \& Akbaş, Y. (2013). The evaluation of the factors affecting the levels of environmental literacy of social science prospective teachers. Pamukkale University Journal of Education, 34(II), 1-14.

Aydin, N. (2008). Influence of class level, seniority and value orientation on self-efficacy beliefs through environmental education of class teachers and proxective teachers. (Unpublished master thesis), Adnan Menderes University Institute of Social Sciences, Aydın.

Azar, A. (2010). In-service and pre-service secondary science teachers' self-efficacy beliefs about science teaching. ZKU Journal of Social Sciences, 6(12), 235-252.

Bandura, A. (1982). Self-efficacy mechanism in human agency. American Psychologist, $37(2), 122-147$.

Bandura, A. (1989). Human agency in social cognitive theory. American psychologist, 44(9), $1175-1184$.

Bandura, A. (1997). Self-efficacy: the exercise of control. Newyork: W. H. Freeman and Company.

Can, A. (2019). Spss ile bilimsel araștırma sürecinde nicel veri analizi. Ankara:Pegem Yayıncllı.

Çavuşoğlu, Ü. G. (2019). An analysis of the relationship between pre-service teachers' environmental education self-efficacy and their attitudes towards sustainable environment. (Unpublished master thesis), Kahramanmaraş Sütçü İmam University Institute of Sciences, Kahramanmaraş.

Çetkin, E. (2019). Determination of education faculty students on self-efficacy beliefs about environmental education. (Unpublished master thesis), Afyon Kocatepe University Institute of Social Sciences, Afyonkarahisar.

Çıngıl Barış, Ç. (2020). Investigation of pre-service science teachers self-efficacy perceptions toward environmental education in terms of different variables. Manisa Celal Bayar University Journal of Social Sciences, 18(4), 113-126.

Erkol, M. \& Erbasan, Ö. (2018). Investigation of teachers' environmental education selfefficacy in terms of different variables. Erzincan University Journal of Education Faculty, 20(3), 810-825.

Erten, S. (2004). Çevre eğitimi ve çevre bilinci nedir, çevre eğitimi nasıl olmalıdır?. Çevre ve Insan Dergisi, 65(66), 1-13. 
Kahyaoğlu, M. (2011). Relationship between the self efficacy beliefs towards environmental education and the learning styles of pre- service teachers. Journal of Educational Sciences Research, 1(2), 67-82.

Karasar, N. (1999). Bilimsel araştırma yöntemi (9. Baskı). Ankara: Nobel Yayın Dağıtım.

Karatekin, K. \& Aksoy, B. (2012). Examination of teacher candidates of social studies' environmental literacy level in terms of various variables. Turkish StudiesInternational Periodical for the Languages, Literature and History of Turkish or Turkic, 7(1), 1423- 1438.

Koç. H. \& Karatekin, K. (2013). An İnvestigation into geography teacher trainees' environmental literacy levels with respect to various variables. Marmara Geographical Review, 28, 139-174.

Koçak Macun, B., Macun, B. \& Safalı, S. (2019). Investigation of teacher self-efficacy levels of teacher candidates and readiness levels for business life. Uluslararası Türkçe Edebiyat Kültür Eğitim Dergisi, 8(1), 549-567.

Konakcl, A. A. (2019). Examination of environmental knowledge and environmental education self-sufficiency levels of science teachers and science teacher candidates through various variables. (Unpublished master thesis), Bayburt University Institute of Social Sciences, Bayburt.

Miller, A. D., Ramirez, E. M. \& Murdock, T. B. (2017). The influence of teachers' selfefficacy on perceptions: Percieved teacher competence and respect and student effort and achievement. Teaching and Teacher Education, 64, 260-269.

Okumuş, S. \& Öztürk, B. (2019). Investigating of preservice elementary teachers' environmental self-efficacy perceptions in terms of various variables. e-Kafkas Journal of Educational Research, 6(2), 9-18.

Önen, F. \& Öztuna A. (2005). Fen Bilgisi ve Matematik Öğretmenlerinin Özyeterlik Duygusunun Belirlenmesi. İstek Vakfı Okulları 1. Fen ve Matematik Öğretmenleri Sempozyumu. İstanbul.

Özbuğutu, E., Karahan, S. \& Tan, Ç. (2014). Environmental education and its alternative methods-a literature review. Mustafa Kemal University Journal of Graduate School of Social Sciences, 11(25), 393-408.

Özdemir, A., Aydın, N. \& Akar Vural, R. (2009). A scale development study on self-efficacy beliefs through environmental education. Dokuz Eylül University the Journal of Buca Faculty of Education, 26(2009), 1-8.

Özlü, G. (2012). The development of 'self efficacy scale in environmental education'. (Unpublished master thesis), University Institute of Educational Sciences, Ankara.

Özyürek, C., Demirci, F., Güler, H., Sarı̈öl, J., Tepe, B. \& Çetinkaya, M. (2019). Investigation of pre-service teachers' environment literacy components by different variables. Mehmet Akif Ersoy University Journal of Education Faculty, 50, 227-253.

Pajares, F. (2002). Gender and perceived self-efficacy in self-regulated learning. Theory into Practice, 4(2), 116-125.

Recepoğlu S. \& Recepoğlu, E. (2020). Relationship between prospective teachers' motivation for teaching profession and sense of efficacy. Hacettepe University Journal of Education, 35(4), 799-814.

Timur, S. (2011). Determining environmental literacy levels of preservice science teachers. (Unpublished Ph. D. thesis ), Gazi University Institute of Educational Sciences, Ankara. 
Turcan, H. G. (2011). Primary school teachers" examination of the relationship between selfefficacy perceptions and satisfactions business. (Unpublished master thesis), Selçuk University Institute of Educational Sciences, Konya.

Türk, Ö. (2008). Research of self-competency and professional satisfaction of primary school teachers. (Unpublished master thesis), Yeditepe University Institute of Social Sciences, İstanbul.

Ünlü, İ., Kaşkaya, A. \& Kızllkaya, M. F. (2017). Examining the self-efficacy beliefs of social studies teacher candidates in terms of some variables. Journal of Kırșehir Education Faculty. 18(2), 651-668

Yılmaz, 0. (2016). Evaluation of social studies and science education's undergraduate programs in terms of environmental education. (Unpublished master thesis), Ahi Evran University Institute of Social Sciences, Kırșehir.

Zayimoğlu Öztürk, F., Öztürk, T. \& Şahin, A. (2015). The investigation of primary school teacher candidates' efficacy perception of environmental education. Amasya Education Journal, 4(2), 293-311.

\section{Biographical Statement}

Gökçe KILIÇOĞLU is an Associate Professor in the Department of Turkish and Social Studies Education at the Gazi University in Turkey. Her studies focus on social studies education. 